\title{
Trust and Distrust Approaches in the Constitutional Lawmaking of Rural Land Rights in Ethiopia: Nature, Drafting and Implications
}

\begin{abstract}
Although rural land rights are recognized in the 1995 Constitution of the Federal Democratic Republic of Ethiopia (FDRE), the academic discourse and policy dialogues on the issue are still underway. However, these dialogues do not comprehensively cover the provisions in the Constitution concerning rural land rights, the modus operandi in the drafting approaches of the provisions and their legal implications. Hence, by analyzing the different sections and articles of the Constitution, this article seeks to examine the extent to which rural land rights are defined in the Constitution and the legal implications of its constitutional recognition. This article examines the compatibility of the approach adopted by Ethiopian Constitution makers with the Trust and Distrust approaches propounded by Rosalind Dixon for drafting of constitutional provisions on rural land rights. Dixon's view is reviewed before considering it in relation with compatibility issues.
\end{abstract}

Brightman Gebremichael *

\section{Key terms}

Rural land rights $\cdot$ Constitutional drafting $\cdot$ Nature of land rights $\cdot$ Ethiopia

DOI http://dx.doi.org/10.4314/mlr.v12i2.5

This article is licensed under a Creative Commons Attribution-NonCommercialNoDerivs (CC BY-NC-ND)

\section{Introduction}

Most written Constitutions of nations are, inter alia, "devoted to establishing and maintaining a system for the allocation (and reallocation) of power over wealth among individuals, groups and the state." 1 Among others, this may be

\footnotetext{
* Brightman Gebremichael: LL.B, and LL.M in Environmental and Natural Resources Law from Bahir Dar University. LL.D University of Pretoria. Assistant professor of law Institute of Land Administration, Bahir Dar University. Email: bgbmichael@gmail.com

The author thanks Prof. Danie Brand, Eden Fesseha, Dr. Muauz Gidey, Dr. Elias Nour and the anonymous reviewers for their helpful comments on the initial draft of the manuscript.

${ }^{1}$ John Henry Merryman (1973), "Ownership and Estate (Variations on a Theme by Lawson)", Tul. L. Rev., Vol. 48, p. 916.
} 
done by recognizing the property rights clause in general without expressly dealing with land rights. ${ }^{2}$ In some countries, Constitutions do not express the recognition of property rights, let alone land rights specifically. ${ }^{3}$ In countries where there is constitutional recognition of property rights, the extent of specificity of the Constitution varies in dealing with property rights. There is variability in the manner property rights are regulated across constitutions. Depending on the general approach pursued by drafters of constitutions, a highly "codified" or detailed approach to constitutional drafting may be used, or the drafters may rely on a more "framework" style approach; ${ }^{4}$.

It is uncommon to find a Constitution that specifically recognizes and defines actual property rights in land. Usually, constitutional laws either state the nature of ownership of land; ${ }^{5}$ or the types of land tenure systems adopted which may include the possibility of deprivation of land rights for public interest and defining the structure and power of land administration organ and tribunals; ${ }^{6}$ or setting social justice policy objectives revolving around land. ${ }^{7}$ However, Ethiopia's Constitution, after distinguishing the nature of land ownership adopted, i.e., ownership by the state and people, ${ }^{8}$ further grants actual rights to rural land specifically. ${ }^{9}$ Moreover, the Constitution goes to the extent of determining the manner of access to rural land rights ${ }^{10}$ and defines the nature of property rights in land. ${ }^{11}$

${ }^{2}$ Gregory S. Alexander (2009), "Property Rights", in Vikram David Amar and Mark V. Tushnet (eds), Global Perspectives on Constitutional Law, Oxford University Press, New York, p. 59.

${ }^{3}$ A case in point is the experience of Canada and New Zealand.

${ }^{4}$ Rosalind Dixon (2015), "Constitutional Drafting and Distrust", International Journal of Constitutional Law, Vol. 13, Issue 4 (819-846), p. 820.

${ }^{5}$ See for instance, The Constitution of the Republic of Rwanda of 2003 Revised in 2015, Official Gazette No. Special of 24/12/2015, Art. 35.

${ }^{6}$ See for instance, Constitution of the Republic of Uganda (1995), Art. 237-243.

7 See for instance, Constitution of the Republic of South Africa (1996), Constitution Seventeenth Amendment Act of 2012 - Government Notice 72 in Government Gazette 36128, dated 1 February 2013. Commencement date: 23 August 2013 [Proc. No. R35, Gazette No. 36774, dated 22 August 2013, Art. 25(4/a), (5) and (6).

${ }^{8}$ Constitution of Federal Democratic Republic of Ethiopia (FDRE) (1995), Art. 40(3).

9 Montgomery Wary Witten (2007), "The Protection of Land Rights in Ethiopia", Afrika Focus, Vol.20, No. 1-2, p. 155.

${ }^{10}$ See FDRE Constitution, supra note 8, Art. 40(4) and (5) about peasants' and pastoralists' free access to rural land rights respectively and Art. 40(6) about private investors access to land rights through payment arrangements.

${ }^{11}$ See Id Art. 40(5) about the pastoralists' property rights in land - use rights; Art. 40(3) in conjunction with Art. 35(7) about peasants' property rights in land - resembling to 
The definition of the nature of property right in land (embodied in the Constitution) is not made in the same fashion to all rural landholders. The Constitution expressly grants use rights to pastoralists based on the communal holding nature of the land, whereas, it does not provide an explicit definition in the case of property rights (in land) of peasants and private investors. Rather, it leaves the nature of property rights in land held by peasants and investors to be understood through the canon of interpretation. This is inferred from the cumulative reading of the constitutionally-prohibited property rights in land, and the sections of the Constitution that deal with women's right and the state governments' power of taxation.

The constitutional norm drafting approach adopted by the FDRE Constitution makers in drafting the provisions dealing with rural land rights is detailed or codified. This is inferred by making a comparison with the constitutional norms of other countries on the same issue and reference to the debates in the making of the Constitution.

The existence or nonexistence of constitutional deferral through 'by law clause' or adoption of abstract or vague concepts in a constitution is not by itself sufficient to classify the drafting approach followed in constitution making into 'framework-style' approach or detailed or codified approach. ${ }^{12}$

Rosalind Dixon suggests that the adoption of a particular constitution drafting approach depends on "the perceived congruence between the constitution makers' aims and the constitution interpreters' understandings thereby giving rise to the dichotomy of trust-mistrust approaches." In her view, constitution drafters adopt a detailed or codified approach in constitutional norms drafting because "they to some degree distrust the constitution interpreters -judges in the supreme or constitutional courts, as they may not share the aims and understandings of constitution drafters." In yet another approach the legislature resorts to framework-style constitutional norm drafting when they "highly trust and has faith in the constitutional judges as partners in the process of constitutional design". 13

It is to be noted that the constitutional recognition of rural land rights under the FDRE Constitution has legal implications on different legal

usufruct rights; and also, Art. 97(2) about private investors and urban land holder property rights in land - usufruct rights.

${ }^{12}$ See Rosalind Dixon (2011), "Constitutional Amendment Rules: A Comparative Perspective", in Rosalind Dixon \& Tom Ginsburg (eds.), Comparative Constitutional Law, Edward Elgar Publishing Ltd, Cheltenham; wherein the claim is made that the constitutional drafting approach adopted in a given constitution making can be determined on the basis of the existence and non-existence of constitutional deferral in the constitution.

${ }^{13}$ R. Dixon, supra note 4. 
concepts. Particularly, it has a legally constraining effect in terms of imposing a duty on the government, restricting legislative power, restraining the amendments to the land policy and raising the constitutionality issue of other legislation and act of the government. These two broad classifications of approaches consider the role players for interpretation of the constitutional provisions as the Courts of Law. In Ethiopia, the interpreter is the House of Federation, the second house/chamber of the federal government, which gives a different perspective altogether.

The constitutional recognition of rural land rights under the FDRE Constitution has its legal implications on different legal concepts. Particularly, it has a legally constraining effect in terms of imposing a duty on the government, restricting legislative power, restraining the amendments to the land policy and raising the constitutionality issue of other legislation and act of the government.

The first three sections of this article examine the rural land right issues regulated under the FDRE Constitution. This includes access to land, the scope of property rights in rural land, and protections afforded to land rights. In order to determine the approach of constitutional drafting adopted in the making of a given constitution, one has to make in-depth analysis of the level of details and scope in the constitutional regulation of a particular legal issue.

Thus, the manner in which access to land is defined in the Constitution and the practical implications thereof -given the limited nature of land as object of property right- are reviewed. The approacch pursued in the Constitution in defining rural land rights is also examined in view of its effect in delimiting the power of the legislative organ in defining the property rights in land in its legislation. This approach is also examined in relation with clarity in the protection against deprivation of property rights in land and the conformity of other legislation with this constitutional stipulation.

The common practice in constitutional laws is to recognize property rights in general ${ }^{14}$ rather than expressly dealing of land rights. Contrary to this, the FDRE Constitution specifically deals with the issue of rural land rights and the general notion of property rights. ${ }^{15}$ The recognition of land rights in the FDRE Constitution mainly embraces three socio-economic and legal issues, i.e., the

\footnotetext{
${ }^{14}$ In fact, there are some constitutions which have not expressly recognised the right to property. A good instance is the constitution of Canada and New Zealand. Constitutions that recognise the right to property vary in terms of providing detailed rules. However, what is common to them is that they forbid arbitrarily deprivation of property rights and provide room for deprivation of property rights for greater societal interest.

${ }^{15}$ See the FDRE Constitution, supra note 8, Art. 40(1 - 8), Art. 35(7) and Art. 97(2).
} 
mechanism of access to land, the scope of property rights in the land of landholders and the features of deprivation of land rights. These themes are examined in the first three sections of this article.

The fourth section of the article explores the general essence of the approaches of constitutional drafting, the approach adopted in the drafting of rural land rights norms under the FDRE Constitution and its compatibility with the nature of the organ entrusted with the power of constitutional interpretation. Section 5 analyses the implications of the constitutional recognition of rural land rights on the basis of three important legal issues. These issues relate to: (i) restriction to the legislative power, (ii) the obligation of the government to realize land rights, the nature of land policy visa-vise amendment of the constitution, and (iii) the constitutionality of other land legislation. The last section offers a brief conclusion about the potential amendment of the land right provisions in the FDRE Constitution to enable them to be compatible with the needs for periodic changes in land policy and optimal trust-based approach to constitution drafting. The article adopts a doctrinal research method. It mainly focuses on identifying, analyzing and synthesizing the constitutional and other legislation provisions.

\section{Access to Rural Land under FDRE Constitution}

One of the legal issues revolving around land rights that are regulated in the Ethiopian Constitution is the mechanism of land acquisition. Access to land is "an important issue for the majority of Ethiopian people who depend on agricultural production for their income and subsistence". 16 That is why the proverb in the many languages of the country has it that 'to be landless is to be sub-human' to show that for Ethiopians land is central to life. ${ }^{17}$ For example, the preamble of Public Ownership of Rural Lands Proclamation enacted in 1975 during the Dergue regime ${ }^{18}$ recognized the centrality of land in the economic, social and political lives of Ethiopians stating that "...a person's right, honor, status and standard of living is determined by his relation to the land..."19

Articles 40(4) and 40(5) of the FDRE Constitution respectively entitle the Ethiopian peasants and pastoralists with the right to access to rural lands for

\footnotetext{
${ }^{16}$ Samuel Gebreselassie (2006), "Land, Land Policy and Smallholder Agriculture in Ethiopia: Options and Scenarios", (Paper prepared for the Future Agricultures Consortium meeting at the Institute of Development Studies, 20-22 March 2006), p. 3.

${ }^{17}$ Paul Brietzke (1976), "Land Reform in Revolutionary Ethiopia", The Journal of Modern African Studies, Vol. 14, No. 4, p. 638.

${ }^{18}$ Amharic for 'council' or 'committee' and it is the socialist regime that governed Ethiopia in the year between $1974-1991$.

${ }^{19}$ See the preamble of the Public Ownership of Rural Lands Proclamation No. 31/1975.
} 
free. ${ }^{20}$ These provisions provide peasants and pastoralists access to rural land without any payment, and they oblige the government to grant the same. On the other hand, investors can be entitled to rural land rights on the basis of payment arrangement which is established by law. ${ }^{21}$

The constitutional right of peasants' and pastoralists' to free access to rural land rights evokes the question whether the rural land use payment imposed on the peasants' especially by subsidiary legislation is constitutional. Most regional states in Ethiopia have enacted laws that levy rural land use payment on peasants and not on pastoralists. ${ }^{22}$ One may argue that this is constitutional based on Article 97(2) of the FDRE Constitution, which states that 'States shall determine and collect fees for land usufructuary rights' ${ }^{23}$ This claim may not be sound for two reasons. First, Article 40(4) of the Constitution clearly states that "Ethiopian peasants shall have the right to obtain land without payment ..." and Article 40(5) enshrines the rights of pastoralists to "the right for free land for grazing". Such free access to rural land rights to peasants and pastoralists differs from the duty for payment of land use fees by investors in return to their entitlement to "land usufructuary rights' stated under Article 97(2). Secondly, Article 40(6) of the Constitution expressly states the rights of investors "to the use of land on the basis of payment arrangements. ${ }^{24}$

The other important issue here is the purpose for which peasants and pastoralists acquire rural land rights for free. Article 40(4) of the Constitution, does not determine the purpose to which the land obtained by peasants without payment will be employed, i.e. whether they can use rural land for agriculture or other economic activities like that of investors. With regard to pastoralists, however, Article 40(5) of the Constitution clearly determines the purpose of land use, i.e., -grazing and cultivation.

The failure of the Constitution to specify the purpose of free allotment of land to peasants while determining the same regarding the pastoralists raises the question whether peasants are entitled to use rural land (which they have obtained without payment) for any purpose. One may also question the constitutionality of the rural land laws in specifying the purpose thereof.

There can be two lines of arguments. On one side, it may be argued that the FDRE Constitution aims at allocating rural land to peasants for free for any

\footnotetext{
${ }^{20}$ FDRE Constitution, supra note 8.

${ }^{21}$ Id at Art. 40(6).

${ }^{22}$ See for instance, the Oromia National State's Revised Rural Land Use Payment and Agricultural Income Tax Proclamation No.131/2007 Art. 3. Most of the States have enacted this type of law that levies rural land use payment.

${ }^{23}$ FDRE Constitution, supra note 8, Art. 97(2).

${ }^{24} I d$, at Art. 40(6).
} 
purpose. Thus, the restriction imposed by another legislation on the purpose to which the land is freely given to peasants for agriculture purpose is unconstitutional. ${ }^{25}$ This argument may be justified first by the silence of the Constitution because, as stated earlier, Article 40(4) of the FDRE Constitution remains silent about the purpose for which land is intended to be provided to peasants for free. At the same time, Article 40(5) fixes the purpose -grazing and cultivation- to which pastoralists are expected to obtain land. Along this line of argument, one may argue that the Constitution rightly and intentionally makes this distinction among the peasants and pastoralists.

The proponents of this line of interpretation may further rationalize this argument based on the manner of land utilization by peasants and pastoralists. In the case of pastoralists, utilization of land is done communally by a group of individuals; and unless the purpose to which the land to be utilized is predetermined, it will cause conflict among the members since each of the members may have a competing purpose to which they prefer to utilize the land. Thus, the Constitution's specification of the purpose for which land is to be allocated to pastoralists for free may be assumed to be purposeful. In the context of peasants', however, the utilization of land is individual thereby implying that the silence of the FDRE Constitution is meant to avoid limitation on the purpose of free allocation of land to peasants. ${ }^{26}$

This line of argument can further raise social equity justification in ensuring access for the needy to provide them with the means to make a living ${ }^{27}$ without restricting the land use of peasants solely to agriculture. This view can be substantiated by the stipulation made in various laws regarding the nature of the purpose for which land can be used by an investor or another peasant who has rented rural land from peasants. In rural land laws enacted at federal and regional state levels, peasants have the right to rent their land to investors or other fellow peasants. ${ }^{28}$ Moreover, the federal government's rural land law implies that the investor and peasants can use such land for agriculture or any development project. This inference can, for example, be made from Proclamation No. 456/2005 which provides that "[p]easant farmers, semi-

${ }^{25}$ See the Federal Rural Land Administration and Land Use Proclamation No. 456/2005, Art. 5(1/a). The same stipulation is provided in almost all States rural land laws . The rural land laws expressly state that the peasants' free access to rural land is granted only if he/she intends to engage in agriculture as his/her livelihood.

${ }^{26}$ This argument unduly presupposes that the communal use and administration is prone to conflict as though it has no customary system of administration. It also assumes that the private holdings and use of peasants have lesser vulnerability to conflict. Moreover, the argument fails to consider communally used land among peasants.

27 See Wibke Crewett and Benedikt Korf (2008), "Ethiopia: Reforming Land Tenure", Review of African Political Economy, No.116, p. 205.

${ }^{28}$ See the Federal Proclamation No. 456/2005, Art. 8(1). 
pastoralists and pastoralists who are given holding certificates can lease to other farmers or investors land from their holding of a size sufficient for the intended development..." 29 The phrase 'intended development' is broad and includes economic activities which can include agriculture and other activities.

The counter argument of the above line of interpretation is that the FDRE Constitution specifies the purpose for which rural land is allocated to peasants for free, and that the stipulation of agriculture in rural land laws to this effect is constitutional. This view may be based on the general spirit of Article 40 of the FDRE Constitution and the assumption of the Constitution makers. The Constitutional Assembly's minutes imply the assumption that the peasants would use land only for agricultural purpose. The first justification of this argument relies on the adoption of the term 'peasants' in Article 40(4) of the Constitution. Accordingly, when the Constitution grants free access to land for peasants under this provision it etymologically presupposes the person's engagement in agriculture.

This argument can be justified in light of the problem that rural land given to peasants for free can be freely transferred under the guise of a joint investment, while private investors are (based on Article 40(6)) entitled to the right to use of land on the basis of payment arrangement. If rural land is given to peasants for free for any purpose, private investors may avoid payment arrangements in their use of land by accessing land through peasants in the pretext of joint investment, ${ }^{30}$ and this, reduces government revenue generated from investors. In fact, one may counter-argue that this form of abuse can be controlled because the government is empowered to approve and register the contract between an investor and a landholder. ${ }^{31}$

The Constitutional Assembly's minutes of the deliberation regarding the form of land ownership implies that the makers assumed that the peasants would use land only for agricultural purpose. Particularly, the justifications (such as agricultural nature of the country's economy and the presence of huge uncultivated-land) that were raised in support of the status quo in land ownership assumed that the landholdings of peasants are only used for agriculture. According to this line of argument, the specification of the purpose for which land is given to pastoralists for free does not imply that peasants would be given rural land to be used for any purpose.

\footnotetext{
${ }^{29}$ Ibid.

${ }^{30}$ Investors can access rural land from individual peasants by way of rent. This is clearly mentioned in the rural land legislation. Thus, the reason mentioned here has no weight to justify the position taken.

${ }^{31}$ The Federal Proclamation No. 456/2005, Art. 8(2).
} 
To this author, the first view is sound and compatible with the country's pursuits toward economic transformation. Unless we consider the silence of the Constitution as entitlement of peasants to use their landholding for any purpose including agricultural cultivation, we can suggest an amendment of the Constitution to make it compatible with the country's economic policy toward industrialization and modernization of agriculture. The challenge in this regard relates to the stringent procedures of constitutional amendment. ${ }^{32}$

In view the objective reality, there is the need to raise the question whether it is practical to implement the right of peasants and pastoralists to free access to land rights. This is impractical because forty-three percent of rural Ethiopians have no access to rural land. ${ }^{33}$ The limited nature of the rural land and the everincreasing rate of population growth have indeed exacerbated the problems because there cannot be comparable expansion of the size of arable land in the country. ${ }^{34}$ Thus, the policy of "guaranteed free access to land" is not sustainable in an environment of rapid population growth, and modern farming which includes animal husbandry should be the main source of subsistence. ${ }^{35}$

\section{Scope of Rights in Rural Land under the FDRE Constitution}

The FDRE Constitution, uncommon to other constitutional norms, ${ }^{36}$ provides its own conception of property rights in general and the nature of property rights to

\footnotetext{
${ }^{32}$ FDRE Constitution, supra note 8, Art. 105(1).

${ }^{33}$ Peter J. Bodurtha et al (2011), "Land Reform in Ethiopia; Recommendations for Reform", (Prepared for Solidarity Movement for a New Ethiopia (SMNE)) available at http://ebookbrowse.com/bodurtha-land-reform-in-ethiopia-pdf-d203740328, retrieved on 05/07/2012, p. 1.

${ }^{34}$ See, for example, Dessalegn Rahmato (2004), Searching for Tenure Security? The Land System and New Policy Initiatives in Ethiopia (FSS Discussion Paper No.12), p.15 and see also World Bank (nd), "Options for Strengthening Land Administration in Federal Democratic Republic of Ethiopia", Report No: 61631-ET, p. 17 for the current rural population.

${ }^{35}$ Tesfaye Teklu (2005), Land scarcity, tenure change and public policy in the African case of Ethiopia: evidence on efficacy and unmet demands for land rights. (The third international conference on development studies in Ethiopia, Addis Ababa, June 18-19, 2005) p. 19; and see also Ethiopian Civil Society Network on Climate Change (ECSNCC) (2011), A Review and Analysis of Land Administration \& Use Legislation and Applications of the Federal Democratic Republic Ethiopia and the Four Regional States of Amhara, Oromia, SNNP and Tigray, p. 42.

${ }^{36}$ There can be certain important textual differences among various constitutional property clauses. Nevertheless, the differences do not go to the extent of defining the concept of 'ownership' and 'private property' and listing of the bundle of rights as it is done in the Constitution of Ethiopia. As Gregory S. Alexander noted, constitutional property clauses are not identical even though they can share certain common features such as the recognition of the state's power of property expropriation as limitation to property rights;
} 
different landholders. It adopts the Hohfeldian 'bundle of rights' approach in defining property rights. ${ }^{37}$ This is inferred from the elements it provides for the concept of private ownership and the provision regarding the rights on the permanent improvement made on land.

According to Article 40(1) of the Constitution, "private property ownership" is defined by listing the rights an owner has over a thing. It states that "... [the right to ownership of private property] includes the right to acquire [possess in the Amharic version] and to use, and ... to dispose of such property by sale or bequest or to transfer it otherwise." 38 According to Article 40(7) of the FDRE Constitution:

Every Ethiopian shall have the full right to the immovable property he builds and to the permanent improvements he brings about on the land by his labor or capital. This right shall include the right to alienate, to bequeath, and, where the right of use expires, to remove his property, transfer his title, or claim compensation for it.

From this provision, it can be inferred that the property rights in the Constitution are understood in terms of the bundle of rights that a person has over objects of property. The other concept related to property rights defined in the Constitution is the concept of private property. The FDRE Constitution under Article40(2), defines private property as:

any tangible or intangible product which has value and is produced by the labour, creativity, enterprise or capital of an individual citizen, associations ( the Amharic version requires the associations to be Ethiopian) which enjoy juridical personality under the law, or in appropriate circumstances, by communities specifically empowered by law to own property in common. ${ }^{39}$

The FDRE Constitution equates "private property" with a thing or asset/product seemingly having economic value. The drafters of the Constitution have unduly defined property as a thing/product since both concepts refer to two distinct things in legal sense. Bruce has noted their distinction as follows:

... [P]roperty is not a thing, but a set of relationship between persons governing the use of things. This is particularly true for land law, which is concerned with various rights over and interests in land which of those a

and placing restrictions on the state's power to expropriate property in the form of permitting the expropriation to be done only for "public purposes" or for "public use".

${ }^{37}$ Wesley Newcomb Hohfeld (1913), "Some Fundamental Legal Conceptions as Applied in Judicial Reasoning”, Yale L. J. Vol. 23, p. 22.

${ }^{38}$ FDRE Constitution, supra note 8, Art. 40(1).

${ }^{39}$ Id., Art. 40(2). 
person can enjoy over his land, which can be enjoyed over that land by his neighbour, and he can enjoy over his neighbour's land. ${ }^{40}$

One may argue that, as the definition of 'private property' currently stands in the FDRE Constitution, rural land right is not the property of peasants and pastoralists since they access it for free. This is because it is not an output or a product of the labor, creativity, enterprise or capital of peasants and pastoralists. This understanding, in effect, produces its own legal effect in relation the legal protection and tenure security against eviction discussed in the subsequent section.

Apart from providing definitional clauses for the above two concepts related with property rights, the FDRE Constitution also determines the nature of the land ownership. Accordingly, Article 40(3) accords ownership to the state and people, prohibits transfer of land through sale or other means of exchange. However, the Constitution does not clearly and expressly define the nature of property rights in land -the bundle of rights accorded to the peasants, the pastoralists and investors lesser than the ownership rights (complete/full property rights).

It does not mean that the Constitution totally leaves it to be determined by the legislation of the government as the ruling government may claim. ${ }^{41}$ This is because the Constitution (through fragmented provisions) attempts to delineate the nature of property rights in relation with rural land held by peasants, pastoralists and investors. One can argue that the constitutional definition of the nature of property right in land for these three bodies is not consistent.

From a contrario sensu reading of Article 40(3) the Constitution, it can be argued that peasants have all the elements of the private 'ownership' rights in land excluding the right to transfer through sale or means of exchange. Unlike peasants', the Constitution has a clear stipulation concerning the property rights in land of the pastoralists and investors. Accordingly, Article 40(5) of the Constitution clearly stipulates that the scope of property rights in land of pastoralists is the use right. The Constitution entitles pastoralists to use rural land for grazing and cultivation purpose. This is in fact based on the manner how pastoralists utilize land - communally. Therefore, letting them other property rights beyond the use right will lead conflict among them since it results in the creation of competing interests.

40 Bruce Ackerman (1977), Private Property and the Constitution, Yale University Press, New Haven and London as cited in Daniel Chappelle (2006), Land Law, ( $7^{\text {th }}$ ed), Pearson Education Ltd, London, p. 20

${ }^{41}$ Brightman Gebremichael (2013), The Role of Ethiopian Rural Land Policy and Laws in Promoting the Land Tenure Security of Peasants: A Holistic Comparative Legal Analysis, (LL.M Thesis, Bahir Dar University, unpublished), p.86. 
This intention of the Constitution drafters can be inferred from the debates made on the drafting of the Constitution regarding the ownership of land. Especially, the group arguing in support of the status quo of the land ownership and against privatization invoked the uniqueness of pastoral land tenure system. The group stated that even if they go for privatization, uniform private property rights to land across the country could not be realized owing to the unique contexts of pastoralists who are in a continuous seasonal mobility across multiple ecosystems in search of the seasonally varying water sources and pasture. ${ }^{42}$ We can thus infer that the drafters intended to differentiate the scope of property rights in land of peasants from pastoralists. Furthermore, it can be inferred from this that the drafters intended to give a broader property right in land to peasants.

In the case of investors too, the Constitution to some extent mentions the nature of property rights in land they will have. This can be deduced from the cumulative reading the two provisions of the FDRE Constitution-Article 40(6) which deals with the manner of acquisition of land rights by investors and Article 97(2) which states the power of regional governments to determine and collect fees in the utilization of land. As per the discussion made in the section dealing with access to rural land in FDRE Constitution above, it has stated that investors could access rural land rights only in payment arrangement, So, when this provision states the phrase land usufructuary rights it in effect is defining the nature of property rights in land of investors.

As the Constitution does not expressly delineate the scope of the property rights of peasants in land, this implies their entitlement to the right to exclude, the right to transfer (without undermining the restriction in the Constitution) and the right to possess and use. This view can also be substantiated with what is provided in the FDRE Constitution with regard to Women's rights. Article 35(7) of the FDRE Constitution that embodies women's right to property also gives a certain clue as to the nature of property rights of peasants in land. It states that: "...In particular, [women] have equal rights with men with respect to use, transfer, administration and control of land."43

42 The Ethiopian Constitutional Assembly Minutes. (Vol. 4, Nov. 23-29/1994, Addis Ababa). Deliberation on Article 40. (Amharic document, author's translation); and see also Belachew Mekuria (2009), "Human Rights Approach to Land Rights in Ethiopia" in Murado Abdo (ed), "Land Law and Policy in Ethiopia since 1991: Continuities and Changes", Ethiopian Business Law Series, Vol. III, p. 59.

${ }^{43}$ See id, at Art. 35(7), Emphasis added. This provision can also apply for the determination of property rights in urban land other than those acquired for investments. For investors acquiring urban land, the nature of property rights in land is similar to their property rights in rural land. This is because Article 97(2) of the FDRE Constitution (that incidentally 
This view can be justified based on the intention of the Constitution drafters that is inferred from their debates in the process of drafting various provisions of the Constitution including Article 40. One of the justifications provided during the arguments against private ownership of land was that such right to sell will induce the agrarian poor to sell land and migrate to the nearby towns, and it will have the effect of escalating unemployment since industrial and services sectors are unable to accommodate the influx of migrants. ${ }^{44}$ The Constitution thus aims at ensuring peasants to have all property rights in land other than the right to transfer through sale or other forms of exchange.

\section{Protection against Deprivation of Rural Land Rights in the FDRE Constitution}

It is "a universal conviction in comparative constitutional law that the purpose of constitutional property rights clause, in general, is to strike a balance between protection of the existing property rights and the promotion of public interest." 45 This balance involves forbidding arbitrary deprivation other than the exceptional cases of compulsory acquisition of individual or community property rights. To strike this balance, most constitutional laws list the conditions that must be satisfied in the process of expropriation, such as observance of due process of law, expropriation solely for public purpose, and payment of just compensation. ${ }^{46}$ These general rules of the constitutional laws are mutants mutandis applicable to the property rights in land.

Viewed this way, the FDRE Constitution recognizes the right to property as a human and democratic right. Nonetheless, unlike other constitutions, it does not make an express rule against arbitrary deprivation of property rights; and the deprivation to be done based on law. It rather defines the government's power of expropriation to deprive this right when the private property is needed for public purpose upon payment of the commensurate amount of compensation. ${ }^{47}$ It is noted that the laws on expropriation define public purpose so wide that it can

mentions the nature of property rights in land of investors) is general and does not make a reference to rural or urban land.

${ }^{44}$ See supra note 42, the Ethiopian Constitutional Assembly Minutes; and B. Mekuria, p.59. Emphasis added.

45 Theunis Roux (2006), "Property" in Stuart Woolman, Theunis Roux and Michael Bishop (.eds), Constitutional Law of South Africa, ( $2^{\text {nd }}$ ed), Juta \& Co LTD, Cape Town, p. 46-2.

${ }^{46}$ The constitutions vary in the extent of elaborating these concepts. (For details on this point see Brightman Gebremichael (2016), "The Power of Land Expropriation in the Federation of Ethiopia: The Approach, Manner, Source and Implications", Bahir Dar University Law Journal, Vol. 7, No. 1).

${ }^{47}$ FDRE Constitution, supra note 8, Art. 40(8). 
also include land to be allocated for investment. ${ }^{48}$ Moreover, it does not incorporate the element of due process of law in the course of the expropriation proceedings. 49

The FDRE Constitution protects peasants and pastoralists against deprivation of rural land rights by granting them the right against eviction. ${ }^{50}$ This right, as part of constitutional property clause, however, is not extended to other rural landholders, like investors and does not apply to other objects of property on the land. Based on the definition of 'private property under the 'FDRE Constitution (discussed above), and the Constituion's provision on expropriation as an exceptional restriction to deprive 'private property', it may seem that the right peasants and pastoralists against eviction and displacement from their land is 'absolute' thereby rendering expropriation inapplicable. Such argument is not valid and their land rights can be deprived through expropriation. ${ }^{51}$

The FDRE Constitution also introduces other grounds of deprivation of property rights in land in a general sense while defining the property rights in the permanent improvements made and things built on the land. The provision states that:

... [full] right shall include the right to alienate, to bequeath, and, where the right of use expires (the Amharic version says 'when the right of land uses terminates), to remove his property, transfer his title, or claim compensation for it." $" 52$

The English version of this provision implies that the property rights in land of any landholder in Ethiopia will be deprived upon the expiration -coming to an end- of the land rights. This would happen when the land right is timebound. In such case, even the Constitution entitles the land rights holder to remove his property (i.e., things that can be removed), and transfer his title or claim compensation for it (when things are not removable without damage). ${ }^{53}$

${ }^{48}$ See, for example, Muradu Abdo (2015), "Reforming Ethiopia's Expropriation Law", Mizan Law Review, Vol. 9, No. 2 (pp. 301-340). http://dx.doi.org/10.4314/mlr.v9i2.3

${ }^{49}$ The due process of law includes the procedural rights such as the right to notice, the right to be heard and the right to appeal. But these elements of due process of law are highly limited in the Ethiopian law of land expropriation.

${ }^{50}$ FDRE Constitution, supra note 8, Art. 40(4) \& (5).

${ }^{51}$ For details about these two dissenting views see Brightman Gebremichael (2016), "Public Purpose as a Justification for Expropriation of Rural Land Rights in Ethiopia", Journal of African Law, Vol. 60, No. 2, pp.200-203.

${ }^{52}$ FDRE Constitution, supra note 8, Art. 40(7).

${ }^{53}$ Emphasis added. Under the urban land lease law of Ethiopia, the lessee is required to remove the property on the land when the lease term expires, and does not guarantee the leaseholder to transfer property on the land to the new landholder or even claim compensation for them. So, the law is unconstitutional in this regard. 
The Amharic version of this provision employs the word 'terminates' instead of 'expires' and this broadens the grounds by which the land rights are lost in addition to the lapse of the duration and expropriation. ${ }^{54}$ One can argue that the Constitution does not foresee such mechanisms of depriving the land rights of peasants and pastoralists. Otherwise, their constitutional right against eviction and displacement becomes superfluous.

The discussion in the preceding sections raises two issues. The first issue relates to the constitutional drafting approach in the 1995 FDRE Constitution along with some discussion on Dixon's categorization of detailed/codified versus framework approaches. Secondly, the legal implications of the drafting approach (used in Ethiopia's Constitution) should be examined. The subsequent two sections address these matters.

\section{The Nature of Drafting Approach adopted in the Rural Land Rights Clause of the FDRE Constitution}

The general approaches in constitutional lawmaking are the 'framework-style' approach in which the constitutional provision embodies "only quite general textual guidance as to the meaning or operation of particular constitutional norms; and a more 'codified' approach, which provides far greater detail or specificity regarding the intended meaning and operation of relevant constitutional norms. ${ }^{, 55}$

The determination of the approach to be followed in the drafting of a particular constitution does not depend upon the general volume or the number of articles incorporated in a constitution. This is because a given constitution may become bulky because of the numerous constitutional issues it addresses but not because of its details in each constitutional provision. Thus, to determine the approach adopted in the drafting of a constitution the extent to which the constitution has gone to detail in regulating a particular constitutional issue should be assessed. It is to be noted that the two approaches may be followed in a single constitution but on different subject matters.

Before determining whether the drafting approach followed is frameworkstyle or 'detailed,' it is necessary to highlight the core features of the framework

\footnotetext{
${ }^{54}$ Since the Constitution separately regulates the issue of expropriation in the subsequent provision under Art. 40(8), this provision is intended to allow the government to terminate land rights based on other grounds to be determined by the legislature. For instance, the rural land laws of Ethiopia incorporate failure to use the land for specific period of time, failure to conserve the land, engagement in non-farming activities, and failure to observe residency requirement as a ground to deprive rural land rights of peasants and pastoralists.

${ }^{55}$ Mila Versteeg \& Emily Zackin (2014), "Towards an Alternative Theory of Constitutional Design”, February 2, 2014 as cited in R. Dixon, supra note 4, p. 820.
} 
style or detailed approaches. Indeed, it is not possible to find hard and fast rules in establishing these issues. As Dixon notes:

[m]ore framework-like approaches will generally involve constitutional provisions in two forms: first, provisions that explicitly defer, or delegate, certain constitutional decisions to legislatures, via the use of language that requires certain constitutional questions to be settled "by law" or by ordinary legislation; and second, provisions that are sufficiently vague or abstract in scope or meaning that they inevitably require some form of judicial interpretation. More codified approaches, in contrast, will generally involve provisions attempting to resolve, rather than defer or delegate, key constitutional questions." 56

One can argue that the existence of constitutional deferral by way of 'by law' clause or vagueness in the provisions ${ }^{57}$ does not necessarily prove the adoption of the framework-style approach in drafting. This is because in constitutional provisions of different countries we find 'by law' clauses or vague or abstract concepts in the form of constitutional deferral on the same subject matter. Such constitutional provisions may differ in the extent to which they regulate the matter.

The rules on compensation upon expropriation of property are illustrative in the constitutions of Ethiopia, Uganda, and South Africa. In Uganda's and South Africa's constitutional provisions on expropriation, there are 'by law' clauses; while the Ethiopian Constitution does not state any 'by law' deferral other than stating an abstract/vague concept of commensurate compensation. ${ }^{58}$ In Uganda's Constitution, it is stated that the compulsory taking of possession or acquisition of property is made under a law which makes provision for prompt payment of fair and adequate compensation, prior to the taking of possession or acquisition of the property. ${ }^{59}$ Under the South African Constitution, it is provided that property may be expropriated only in terms of law of general application ...subject to compensation. ${ }^{60}$ The South African Constitution further deals with the factors to be considered in the determination of the amount of compensation. Unlike the Ugandan and Ethiopian Constitutions, it states that:

\footnotetext{
${ }^{56}$ R. Dixon (2011), supra note 12.

${ }^{57}$ For detail on the forms of Constitutional deferral, see Rosalind Dixon and Tom Ginsburg (2011), "Deciding not to decide: Deferral in constitutional design", International Journal of Constitutional Law, Volume 9, Issue 3-4; pp. 636-672, https://doi.org/10.1093/icon/mor041

58 FDRE Constitution, supra note 8, Art. 40(8).

${ }^{59}$ Ugandan Constitution, supra note 6, Article 26(2/b-i).

${ }^{60}$ South African Constitution, supra note 7, Art. 25(2/b).
} 
The amount of the compensation and the time and manner of payment must be just and equitable, reflecting an equitable balance between the public interest and the interests of those affected, having regard to all relevant circumstances, including-

(a) the current use of the property;

(b) the history of the acquisition and use of the property;

(c) the market value of the property;

(d) the extent of direct state investment and subsidy in the acquisition and beneficial capital improvement of the property; and

(e) the purpose of the expropriation. ${ }^{61}$

The South African Constitutional provision seems to have adopted the detailed approach in lawmaking, as compared to its Ugandan and Ethiopian counterparts. Yet, all of them provide for defer detail provisions by either using 'by law' clauses or by adopting a vague/abstract concept that requires definition through legislation. The approach adopted in the drafting of a given state's constitutional rules should thus be determined by comparing it with other states' constitutional rules on the same subject.

Rosalind Dixon argues that the choice to adopt either a highly "codified" or detailed approach to constitutional drafting or to rely on a more "framework"style approach, depends on the perception the constitution makers towards constitutional courts as partners in the process of constitutional interpretation. According to Dixon, "the codified or the detailed approach implicitly assumes at least some degree of distrust toward judges as constitutional interpreters, whereas the framework"-style approach is based on a high degree of faith or trust, in judges as partners in the process of constitutional design., 62

Dixon's observations do not explain the constitutional drafting approach adopted in the drafting of rural land rights clause and the nature of constitutional interpreter organ in Ethiopia. The first factor relates to the similarity and difference between constitutional provisions of countries that cannot be explained by Dixon's trust and distrust approaches in constitutional lawmaking. As highlighted in the preceding paragraphs, The South African Constitution adopts a detailed or codified approach in drafting provisions of compensation during expropriation of property in contrast to the Ethiopian and Ugandan Constitutions. Nevertheless, with regard to the issue of citizenship, the approach followed by the South African Constitution ${ }^{63}$ pursues a more of framework-style as compared to the Ethiopian ${ }^{64}$ and Ugandan Constitutions. ${ }^{65}$

\footnotetext{
${ }^{61}$ Id at Art. 25(3)

${ }^{62}$ R. Dixon, supra note 4, p. 820.

${ }^{63}$ South African Constitution, supra note 7, Art. 3. The article entitles all citizens to equal rights, privileges and benefits subject to equal duties and responsibilities, and it totally
} 
This change in the approach of drafting provisions of the constitution may lead to question why South African Constitution that adopts a distrust-based approach in drafting provision of compensation for expropriation adopts trustbased approach regarding the issue of citizenship. Likewise, the Ugandan Constitution adopts a trust-based approach in drafting provision of compensation for expropriation and opts for a distrust-based approach in the case of rules of citizenship. Such variations occur in both constitutions even though the constitutional interpreter is the same body. We can thus conclude that the adoption of framework -style or detailed/codified approach of constitutional drafting does not necessarily depend on the perception of the constitutional makers towards the judges of constitutional interpretation.

Second, the constitutional makers may follow a detailed/codified approach of drafting constitutional provisions even where they have a faith and trust on the constitutional interpreter. For example, the Ethiopian Constitution uses the detailed approach in drafting rural land rights even if all constitutional interpretation constitutional disputes are according to Articles 62(1) and 83(1) decided by a non-judicial organ, i.e. the House of Federation on which constitutional makers have faith and trust.

The existence of this trust can be inferred from the justifications provided for assigning the power of constitutional interpretation to this organ at the time of the constitutional drafting. The justifications are twofold. The first one is related to the belief that the owner of the constitution should interpret it. Accordingly, the FDRE constitutional makers thought that the new federal dispensation is the outcome of the 'coming together' of the nationalities, and the FDRE Constitution is the reflection of their 'free will and consent.' In fact, this is expressly reflected in the preamble and Article 8 of the FDRE Constitution while saying the 'nations, nationalities and peoples are sovereign.' Then the constitutional makers considered the Constitution as 'a political contract' and consequently, only the authors that are the nations, nationalities and peoples should be the ones to be vested with the power of interpreting the Constitution. ${ }^{66}$ To this effect, the

defers to the national legislature to determine the manner of acquiring, losing and restoring of citizenship.

${ }^{64}$ FDRE Constitution, supra note 8, Art. 6. The article defined the manner of acquiring Ethiopian nationality and how a foreign national can acquire Ethiopian nationality.

${ }^{65}$ Ugandan Constitution, supra note 6, Art. 9 to19. The articles in detail regulate all issues revolving around citizenship.

${ }^{66}$ Assefa Fiseha (2007), "Constitutional Adjudication in Ethiopia: Exploring the Experiences of the House of Federation", Mizan Law Review, Vol. 1, No. 1, p.10; and also see K. I. Vibhute (2014), "Non-Judicial Review in Ethiopia: Constitutional Paradigm, Premise and Precinct”, Afr. J. Int'l \& Comp. L., Vol. 22, p.128. 
constitutional interpreting organ -House of Federation- is composed of the representatives of the various nations, nationalities, and peoples. ${ }^{67}$

The assignment of this power to the House of Federation is also related to the distrust (that the ruling party which controlled of majority votes among constitutional makers had) towards the judiciary. The FDRE constitutional makers perceived that empowering the judiciary, or a constitutional court may result in unnecessary 'judicial adventurism' or what some prefer to call 'judicial activism' in which the judges would in the process of interpreting vague clauses of the Constitution put their own preferences and policy choices in the first place. They believed that this in turn could hijack the very document that contains the 'compact between the nations', 'nationalities' and 'peoples' thereby resulting in decisions that rather fit the personal philosophies of judges. ${ }^{68}$

Therefore, this author argues that the reason for the adoption of the detailed rule regarding the rural land rights can be related with the debates and diversified views at the making of this clause ${ }^{69}$ and the level of sensitivity of the issue. ${ }^{70}$ The nature of the debate can be inferred from the very close voting made in the enactment of Article 40(3) of the Constitution by the constitutional assembly whereby 499 voted for the retention of state ownership of land, whereas 495 voting for privatization.

In fact, the problem in the adoption of the codified/detailed approach in rural land rights relates to the incorporation of detail rules to regulated rural land rights in the Constitution which should have merely determined the nature of land ownership. The following section discusses the problems that emanate owing to such detail constitutional stipulations on rural land rights.

\section{Implications of the Constitutional Recognition of Rural Land Rights under FDRE Constitution}

The FDRE Constitution grants actual rights to rural land specifically contrary to the constitutions of other countries and international human rights instruments. As discussed above, Article 40 of the FDRE Constitution expressly grants the

\footnotetext{
${ }^{67}$ FDRE Constitution, supra note 8, Art. 61(1) and (2).

${ }^{68}$ See supra note 66, A. Fiseha, p. 11 and K. I. Vibhute, p.128.

${ }^{69}$ Gebru Mersha and M. Githinji (2005), Untying the Gordian Knot: The Question of Land Reform in Ethiopia, (ISS/UNDP Land, Poverty and Public Action Policy Paper No.9, The Hague: Institute of Social Studies).

${ }^{70}$ As stated in the first section (paragraph 1) of this article the sensitivity of the land issue is noted by P. Brietzke, supra note 17, p. 638. and the preamble of Proclamation No. $31 / 1975$ ). With regard to the 'Land to Tiller' student movement that caused the downfall of the last emperor, see, for example, Daniel Weldegebriel (2012), "Land Rights in Ethiopia: Ownership, equity, and liberty in land use rights", (FIG Working Week Rome, Italy, 6-10 May 2012) p .4.
} 
Ethiopian peasants and pastoralists with free access to rural land and while private investors are accorded the right based on payment arrangements. The Constitution further also ensures peasants and pastoralists with the right to protection against eviction and displacement. Moreover, the Constitution defines the nature of property rights in land. The level of details in the constitutional recognition of rural land rights will have its implications on the restriction of legislative power and the obligation of the government to realize the land rights.

The first challenge that is created by level of details in the Constitution relates to the obligation of the government to ensure the implementation of the constitutional rights of peasants and pastoralists for access to land without payment. To this end, Article 13(1) of the Constitution imposes a duty on the government to enforce the fundamental rights and freedoms embodied therein including access to rural land rights enshrined Articles 40(4) and 40(5).

The second implication of the detailed approach in the constitutional recognition of rural land rights in the FDRE Constitution is related with the nature of land policy that need to be flexible so that it can be responsive to changing realities. This creates rigidity on the land regime owing to the stringent procedures in the amendment of constitutions. The details in the constitutional recognition of rural land rights in the FDRE Constitution indeed imply restrictions against the legislative power of the legislature. ${ }^{71}$ While regulating the issues of rural land rights under the human rights section, the FDRE Constitution defines the rural land policy of the country. This situation effectively eliminates the possibility of flexible application of policy. ${ }^{72}$ The legal framework for land rights should not only be comprehensive, but should also be flexible, allowing for different options depending on population density, the level of economic development, and infrastructure access. ${ }^{73}$

Accordingly, the Ethiopian rural land regime expressed in the Constitution is inflexible to be compatible with the changing socio-economic lives of the society. This is because the modification of the rural land policy of the country needs the amendment of the Constitution which has stringent amendment procedures. Article 40 of which embodies the rights on land is classified under the human and democratic rights section which has a more stringent procedure

${ }^{71}$ Not to enact contradictory rules in enacting legislation. This is because under article $9(1)$ of the FDRE Constitution it is provided the self-supremacy clause - supremacy of the constitution and declared that any law... of an organ of state...which contravenes the constitution shall be of no effect.

${ }^{72}$ S. Gebreselassie, supra note 16, p. 4.

${ }^{73}$ See Klaus Deininger (2003), Land Policies for Growth and Poverty Reduction, The World Bank, Washington DC, p. 51. 
for amendment. ${ }^{74}$ Moreover, the inflexibility of the provisions is aggravated by the absence of commitment to that effect from the side of the ruling party which has the lion share of seats in the State Councils of the federative units and the two federal Houses (the House People's Representatives and the House of Federation) which are empowered to amend the constitution jointly. ${ }^{75}$ This was clearlly expressed by late Prime Minister Meles Zenawi during his end-of-year report to Parliament in June 2004 when he the announced that the change of land policy in Ethiopia would take place only "over his party's -Ethiopian People's Democratic Revolutionary Front's- tombstone". 76

The final important implication is that the constitutional recognition of rural land rights in the Constitution will lead to the ramification of the question of the constitutionality of the rural land legislation in regulating the rural land rights. For example, the rural land legislation (with an exception to Amhara State's Rural Land law) prohibits peasants from using their land rights as collateral. ${ }^{77}$ As immovable property, land is often the best form of security for a loan. A landholder may grant an interest in his land as security (known as a mortgage) in favor of a person in return for a loan. ${ }^{78}$ Access to credit is often a critical question in rural areas which requires land to be used as collateral. ${ }^{79}$ As De Soto notes, land tenure could unlock the entrepreneurship of poor people by letting them use their real estate assets (including land rights) as collateral to borrow investment capital. ${ }^{80}$

Contrary to such crucial importance of land rights, the rural land legislation in Ethiopia even impliedly prohibits peasants from using their land rights as collateral to access loan. This can be inferred from the definition given to the

\footnotetext{
${ }^{74}$ FDRE Constitution, supra note 8, Art. 105(1)

${ }^{75}$ Since the adoption of the FDRE Constitution in 1995, the seats in all State councils of the federations and the two federal houses have been by dominated by the ruling party, Ethiopian People's Democratic Revolutionary Front (EPDRF).

${ }^{76}$ Stephen Devereux et al (2005), "Too Much Inequality or Too Little? Inequality and Stagnation in Ethiopian", Institute of Development Studies Bulletin, Vol. 36, No. 2, p.122. However, with the coming into power of Prime Minister Abiy Ahmed there is a possibility of change of the ruling party's rigid position on the land regime.

77 The 2018 Amhara State's Rural Land Law authorizes the peasants to use their land rights as collateral to secure loan. This stipulation also raises the question whether Regional States in Ethiopia have the power to delineate the property rights in land.

${ }^{78}$ SH Goo (2002), Sourcebook on Land Law, ( $3^{\text {rd }}$ ed), Cavendish Publishing Ltd, p. 813.

${ }^{79}$ Paul De Wit et al "2009", Land Policy Development in an African Context: Lessons Learned from Selected Experiences, FAO Land Tenure Working Paper 14, p. 63.

${ }^{80}$ Hernando De Soto (2000), The mystery of capital: Why capitalism triumphs in the West and fails everywhere else, Black Swan, New York. See also Gregory K. Ingram and YuHung Hong (eds) (2009), Property Rights and Land Policies, (Proceedings of the 2008 Land Policy Conference) p. xi.
} 
property rights in land of peasants and from the provision of the rural land legislation that allow mortgaging to investors expressly. ${ }^{81}$ The rationale that is stated by the Ethiopian government is that the sale, mortgage, or use of land as collateral is expressly prohibited to prevent the development of exploitative land arrangements. ${ }^{82}$

Since rights should be interpreted broadly and limitation should be constructed restrictively, ${ }^{83}$ it can be argued that this prohibition is unconstitutional. If it is argued that the Constitution does not allow rural land right holders to mortgage their land rights based on the prohibition of sale and exchange (stated under Article 40/3), then the express authorization of private investors $^{84}$ and also urban land right holders ${ }^{85}$ to use their land rights as collateral will be unconstitutional. It is to be noted that Article 40(3) of the Constitution refers to all landholders including investors and urban landholders. Thus, either way, it raises the question of constitutionality.

\section{Concluding Remarks}

A detailed recognition of the rural land rights -more than stating the nature of land ownership and regulating it under the general property rights - in the FDRE Constitution, has resulted in an inflexible land regime which is not responsive to the change of circumstances. This is susceptible to persistent and continued demand from peasants and pastoralists for the realization of their right to free allotment of land, which cannot be achieved owing to the limited nature of the land and Ethiopia's steadily increasing population. As land is inelastic, the government cannot continue providing land to peasants and pastoralists particularly in light of the rate of population growth and Ethiopia's slow pace in industrialization, import substitution and export enhancement that could have reduced the economy's substantial reliance on smallholder rural land cultivation.

Moreover, detailed statements of constitutional rights on land limit the power of the government to define the property rights in land. The paradox in this regard is that such detail constitutional lawmaking against eviction and dispossession of peasants and pastoralists has not inhibited the enactment of

\footnotetext{
${ }^{81}$ See Proclamation No. 456/2005, Art. 2(4) and Art. 8(4).

${ }^{82}$ See for instance, PJ. Bodurtha, Peter J. et al, supra note 33, p. 6; D. Rahmato, supra notes 34, pp. iii and 14; Stefan Decron and Daniel Ayalew (2007), "Land Rights, Powers and Trees in Rural Ethiopia", CSAE WPS/2007-07, p.6; Government of the Federal Democratic Republic of Ethiopia (2003), Rural Development Policy and Strategies,p.24.

${ }^{83}$ Francis G. MorriseyOmi (2012), "Strict interpretation helps avoid Harshness"' Health Progress.

${ }^{84}$ See Proclamation No. 456/2005, Art. 8(4).

${ }^{85}$ See the Federal Urban Lands Lease Proclamation No.721/2011, Art. 24(1).
} 
unconstitutional proclamations that embody absurd and extensive land expropriation powers of the government. These realities lead to the questionable constitutionality of the subsequent rural land legislation and the acts of the government.

The constitutional drafting approach adopted in the rural land rights clause of the FDRE Constitution is not compatible with Dixon's trust approach. Given that the constitutional interpreter in Ethiopia -House of Federation- is the organ composed of representatives of the (assumed to be) authors of the Constitution nationalities, the drafters would have followed 'framework-style' approach. However, this state of affairs casts doubt on the validity of the premises in of Dixon's view that relates constitutional drafting approaches with the perception of constitutional makers towards the constitutional interpreter. In her view, constitutional drafters follow a framework-style constitutional drafting approach when they trust and regard the constitutional interpreter as a partner in the constitutional designing. The detailed or codified approach is adopted in case the drafters distrust the constitutional interpreter. She also defines the adoption of a particular constitutional drafting approach based on the presence or absence of 'by law' deferrals and vague and abstract concepts in the Constitution.

I argue that determining the constitutional drafting approach adopted by constitutional makers cannot only be determined by looking into the existence or nonexistence of 'by-law' deferral or vague concepts. It should rather be complemented with the comparative analysis of the constitutional laws of different states on the same subject matters. Furthermore, the adoption of one of the approaches may not be justified only on the trust-distrust dichotomy of the constitutional interpreter. This is because in a given constitution, which is subjected to a single interpreter organ, it is possible to find both drafting approaches in different constitutional matters. Moreover, even in the presence of a trusted constitutional interpreter, the detailed approach of a constitutional clause may be adopted as in the case of rural land rights provision of FDRE Constitution.

Therefore, determination of the constitutional drafting approach followed by a given constitutional drafter should be issue-specific. It should be done by analyzing specific constitutional matters and comparing the existence and nonexistence of constitutional deferral among constitutional laws of different countries. Furthermore, the selection of the approach may not be solely affected by the perception of constitutional drafters towards constitutional interpreters. It, rather, may be influenced by the extent of diversity of views and debates on the issues and by the level of sensitivity of the issue. 